\title{
Empirical Study on Enhancing Medical Service Performance with Intellectual Capital through Process Capability
}

\section{Ya-Ping $\mathrm{Hu}^{1}$}

Assistant Professor

Department of Accounting and Information Systems

Asia University

Taiwan, ROC.

E-mail: yapinghu@asia.edu.tw

\section{Taiwan}

\section{Yi-Ming Chiang}

Graduate student

Department of Information Management

National Chung Cheng University

Taiwan, ROC.

E-mail: andy082220@gmail.com

Taiwan

\section{ABSTRACT}

This study investigates the synergistic relationships among intellectual capital, process capability, and medical service performance. An empirical study was conducted by using a second-order research framework. Data were collected through a questionnaire survey, and structural equation modeling techniques were used to analyze the data. An empirical analysis revealed that intellectual capital is a major factor influencing final medical service performance. This major factor should be carefully improved to increase process capability in hospitals in the long term. Hospitals account for a substantial proportion of the intellectual capital in the health-care industry, and, thus, should improve their process capability to achieve high medical service performance.

\section{KEYWORDS: Intellectual capital; health-care industry; process capability; medical service performance.} \section{Introduction}

To optimize medical service processes (MSP) for healthcare providers, medical organizations depend on professional knowledge to effectively integrate and analyze clinics, prescriptions, billing, supply chains, and patient relationships, in and across organizational boundaries (Wu \& $\mathrm{Hu}, 2012)$. According to Nursing Intellectual Capital Theory (NICT) (Covell \& Sidani, 2013a, 2013b), the health-care industry is a very complex and high knowledge-intensive industry that relies on the synergies of intellectual capital (IC), process capability (PC), and medical service performance (MSP). Many studies are exploring the relationship between IC and MSP, most of which focus on the impact of IC on medical professionals (Covell \& Sidani, 2013a). However, few studies have examined the relationship between IC and MSP from a management and process perspective. Hence, we propose a research model that clarifies the relationships between IC and MSP with a management perspective of PC in a hospital. Since Taiwan's National Health Insurance system is very successful (Cheng, 2015; Wu et al., 2010), we target the medical institutions in Taiwan. The contribution of this research is not only to find out the relationship between IC and MSP but also to put forward the emphases of management PC, which can be used as a reference for the medical industry.

\section{Research Model and Literature Review}

We use graphical representations to explain the core issues of this study, then depicted the analytical research model as Figure 1. And this study proposes three hypotheses and verifies them if these three hypotheses are acceptable to understand the relationship between IC, PC, and MSP. 


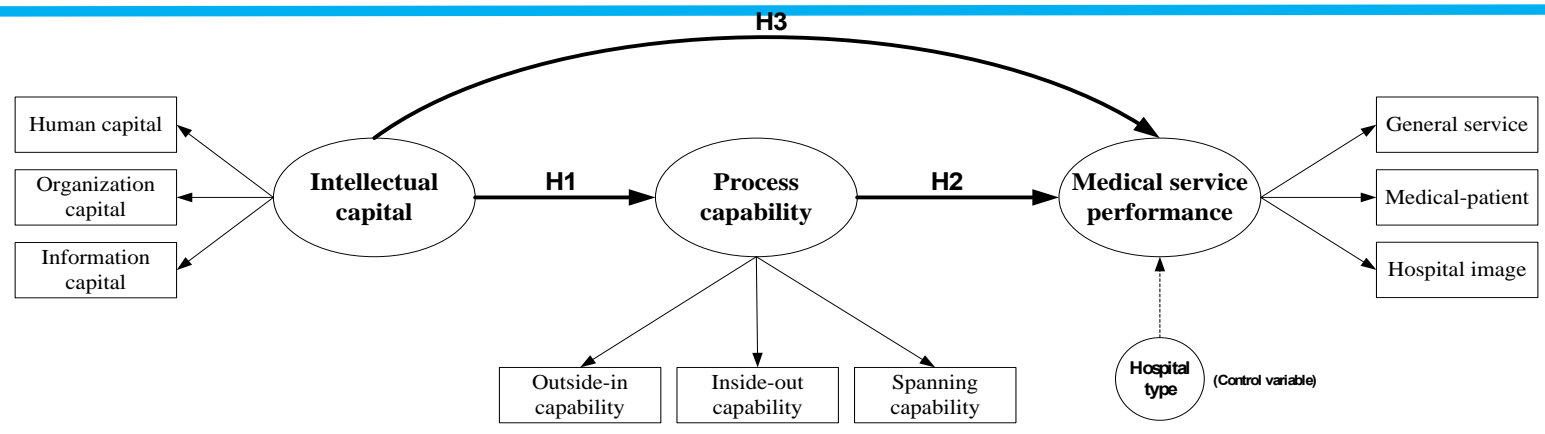

Fig 1. Research model

The three hypotheses and the subjects of this research are as follows:

H1: Intellectual capital is positively associated with process capability.

H2: Process capability is positively associated with medical service performance.

H3: Intellectual capital is positively associated with medical service performance directly.

Intellectual capital (IC): According to the definition of IC in the nursing and medical domain: (1) nursing human capital (NHC), (2) nursing structural capital (NSC), (3) nurse staffing (NS), and (4) employer support for nurse continuing professional development (CPD). Therefore, based on NICT and previous studies (Dumay \& Garanina, 2013; Serenko \& Bontis, 2013), we define the three subconstructs of IC as human capital, organization capital, and information capital. The contents for IC as table 1. of NICT (Covell \& Sidani, 2013a), there are four elements

Table 1. Contents of IC

\begin{tabular}{|c|c|c|}
\hline Subconstructs of IC & Contents & Source \\
\hline Human capital (IC) & $\begin{array}{l}\text { Knowledge, skill, capability, work-related } \\
\text { competence, experience, expertise, and } \\
\text { personality traits }\end{array}$ & $\begin{array}{l}\text { Dzenopoljac et al., 2017; Dumay \& } \\
\text { Garanina, 2013; Serenko \& Bontis, } \\
2013\end{array}$ \\
\hline Organization capital (OC) & $\begin{array}{l}\text { External attribute: customers, suppliers, } \\
\text { and competitors. } \\
\text { 2. Internal attribute: corporate culture, } \\
\text { management processes, organizational } \\
\text { structures, }\end{array}$ & $\begin{array}{l}\text { Dumay \& Garanina, 2013; } \\
\text { Dzenopoljac et al., 2017; Serenko \& } \\
\text { Bontis, 2013; Dumay \& Garanina, } \\
\text { 2013; Serenko \& Bontis, } 2013\end{array}$ \\
\hline Information capital (IC) & $\begin{array}{l}\text { Infrastructure and applications that support an } \\
\text { organization's strategies }\end{array}$ & $\begin{array}{l}\text { Devaraj et al., 2013; Komnenić \& } \\
\text { Pokrajčić, 2012; Dumay \& Garanina, } \\
\text { 2013; Serenko \& Bontis, 2013; } \\
\text { Westbrook et al., } 2013\end{array}$ \\
\hline
\end{tabular}

Process capability (PC): Based on past research consist of these three dimensions: outside-in capability, (Brahma \& Chakraborty, 2011; Bromiley \& Rau, 2016; inside-out capability, and spanning capability. The contents Coleman et al., 2013; Wu \& Hu, 2012), we consider PC to for IC as table X

Table 2. Contents of PC

\begin{tabular}{l|l|l}
\hline \multicolumn{1}{c|}{ Subconstructs of PC } & \multicolumn{1}{c}{ Contents } & \multicolumn{1}{c}{ Source } \\
\hline Outside-in capability (OIC) & $\begin{array}{l}\text { Industrial environment, long-term } \\
\text { relationships with external stakeholders, } \\
\text { respond to market changes quickly }\end{array}$ & $\begin{array}{l}\text { Inauen \& Schenker-Wicki, 2011; } \\
\text { Inauen \& Schenker-Wicki, 2011 }\end{array}$ \\
\hline Inside-out capability (IOC) & $\begin{array}{l}\text { Operations in internal processes, service } \\
\text { innovation, logistics, medical processes, } \\
\text { customer service, technology }\end{array}$ & $\begin{array}{l}\text { Ngo \& O'cas, 2013; Hu et al., } \\
\text { 2017 }\end{array}$ \\
\hline Spanning capability (SPC) & $\begin{array}{l}\text { Integrate outside-in and inside-out } \\
\text { capabilities, strategy development, } \\
\text { organizational collaboration, } \\
\text { information integration, information } \\
\text { system planning }\end{array}$ & $\begin{array}{l}\text { Bernroider, 2014; Coleman et al., } \\
\text { 2013; Zhang et al., 2011 }\end{array}$ \\
\hline
\end{tabular}


Medical service performance (MSP): Regarding scholars that the measurement of MSP was at the the definition of MSP, many scholars have put forward multiple views in the past (He, 2014WHO, 2015; Varagunam et al., 2013; Huang \& Jerng, 2014; Lee et al. (2010; Gebicki et al., 2014; Alkhenizan \& Shaw, 2011; Hung \& organization level, and considering the perspectives from WHO and integrating past research, this study defined MSP as consisting of three subconstructs: general service level, Jerng, 2014; Francis et al., 2016). We adopted the views of all contents for IC as table 3.

\section{Table 3. Contents of MSP}

\begin{tabular}{l|l|l}
\hline \multicolumn{1}{c|}{ Subconstructs of MSP } & \multicolumn{1}{c}{ Contents } & \multicolumn{1}{c}{ Source } \\
\hline General service level (GS) & $\begin{array}{l}\text { Responsive governance, staff } \\
\text { orientation, efficiency, healthcare } \\
\text { quality }\end{array}$ & $\begin{array}{l}\text { WHO, 2015; He, 2014; } \\
\text { Varagunam et al., 2013; Huang } \\
\text { \& Jerng, 2014; }\end{array}$ \\
\hline $\begin{array}{l}\text { Medical-patient relationships } \\
\text { (MP) }\end{array}$ & $\begin{array}{l}\text { Clinical effectiveness, safety, patient } \\
\text { centeredness, and doctor-patient } \\
\text { relationship. }\end{array}$ & $\begin{array}{l}\text { Alkhenizan \& Shaw, 2011; Lee } \\
\text { et al., 2010; }\end{array}$ \\
\hline Hospital image (HI) & $\begin{array}{l}\text { Reputation, hospital promote its rank } \\
\text { in customer surveys }\end{array}$ & $\begin{array}{l}\text { Wu \& Hu, 2012; Hung \& } \\
\text { Jerng, 2014 }\end{array}$ \\
\hline
\end{tabular}

Questionnaire design: The survey instrument consisted of a two-part questionnaire. The first part used a nominal scale to collect basic information on the hospital and the respondent. The second part of the questionnaire was prepared by considering previous research, and a 7-point Likert scale was used to evaluate the hospital's IC, PC, and MSP. Also, after discussion with five experts in the medical industry, we considered the hospital type as the control variable.
Sampling: We aimed at general hospitals in Taiwan, excluded primary clinics and specialist hospitals. The sample contained a total of 437 hospitals selected from the list of hospitals published by the Taiwan Joint Commission on Hospital Accreditation for the year 2017. A total valid sample size was 128 (overall response rate: 29.3\%). The demographics of the samples are presented in Table 4.

Table 4. Demographics of the samples

\begin{tabular}{|c|c|c|}
\hline & Frequency & Percent (\%) \\
\hline \multicolumn{3}{|l|}{ Hospital types } \\
\hline Medical center & 8 & 6.3 \\
\hline Regional hospital & 63 & 49.2 \\
\hline District hospital & 57 & 44.5 \\
\hline \multicolumn{3}{|c|}{ Annual revenue $\mathrm{M}$ : million, B: billion } \\
\hline $\begin{array}{l}<100 \mathrm{M} \\
100 \mathrm{M} \sim 500 \mathrm{M} \\
500 \mathrm{M} \sim 1 \mathrm{~B} \\
1 \mathrm{~B} \sim 5 \mathrm{~B} \\
5 \mathrm{~B} \sim 10 \mathrm{~B} \\
>10 \mathrm{~B} \\
\end{array}$ & $\begin{array}{c}18 \\
44 \\
31 \\
20 \\
13 \\
2 \\
\end{array}$ & $\begin{array}{c}14.1 \\
34.4 \\
24.2 \\
15.6 \\
10.2 \\
1.6 \\
\end{array}$ \\
\hline \multicolumn{3}{|c|}{ Number of employees } \\
\hline $\begin{array}{l}<500 \\
501 \sim 1000 \\
1001 \sim 1500 \\
1501 \sim 2000 \\
>2000 \\
\end{array}$ & $\begin{array}{r}5 \\
41 \\
42 \\
33 \\
7 \\
\end{array}$ & $\begin{array}{r}3.9 \\
32.0 \\
32.8 \\
25.8 \\
5.5 \\
\end{array}$ \\
\hline \multicolumn{3}{|c|}{ Respondent's working experience } \\
\hline $\begin{array}{l}<5 \text { years } \\
5 \sim 10 \text { years } \\
10 \sim 20 \text { years } \\
\text { 20 30 years } \\
>30 \text { years } \\
\end{array}$ & $\begin{array}{r}20 \\
61 \\
37 \\
8 \\
2 \\
\end{array}$ & $\begin{array}{r}15.6 \\
47.7 \\
28.9 \\
6.2 \\
1.6 \\
\end{array}$ \\
\hline Respondent's educa & & \\
\hline
\end{tabular}




\begin{tabular}{|c|c|c|}
\hline $\begin{array}{l}\text { High school } \\
\text { College } \\
\text { Graduate } \\
\text { Ph.D. } \\
\end{array}$ & $\begin{array}{r}3 \\
89 \\
33 \\
3 \\
\end{array}$ & $\begin{array}{r}2.3 \\
69.5 \\
25.8 \\
2.3\end{array}$ \\
\hline \multicolumn{3}{|c|}{ Respondent's gender } \\
\hline $\begin{array}{l}\text { Female } \\
\text { Male } \\
\end{array}$ & $\begin{array}{l}67 \\
61 \\
\end{array}$ & $\begin{array}{l}52.3 \\
47.7 \\
\end{array}$ \\
\hline \multicolumn{3}{|c|}{ 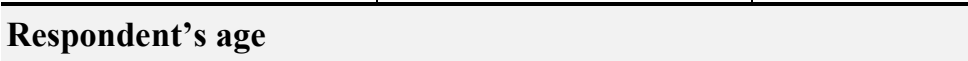 } \\
\hline $\begin{array}{l}<30 \\
30 \sim 40 \\
40 \sim 50 \\
50 \sim 60 \\
>60 \\
\end{array}$ & $\begin{array}{c}25 \\
72 \\
27 \\
4 \\
0 \\
\end{array}$ & $\begin{array}{r}19.5 \\
56.2 \\
21.1 \\
3.1 \\
0\end{array}$ \\
\hline \multicolumn{3}{|c|}{ Respondent's position } \\
\hline $\begin{array}{l}\text { Management } \\
\text { Medical } \\
\text { Other }\end{array}$ & $\begin{array}{l}63 \\
50 \\
15\end{array}$ & $\begin{array}{l}49.2 \\
39.1 \\
11.7\end{array}$ \\
\hline
\end{tabular}

Nonresponse bias: To ensure that no nonresponse bias existed, the respondents were divided into two groups: an early group containing 86 respondents and a late group comprising 42 respondents. The two groups were compared by considering various organizational characteristics that were determined by using the $t$-test. No significant differences were observed between the two groups at the .05 level $(t$ value $=$ $0.85,0.31$, and 0.41$)$. This result indicated that no systematic nonresponse bias existed among the respondents.

Scale validation: The convergent validity was assessed using three criteria: (1) all item loadings $(\lambda)$ should be statistically significant and exceed $0.70,(2)$ the composite construct reliability of each construct should exceed 0.80 and should be interpreted as Cronbach's $\alpha$ coefficient is interpreted, and (3) the average variance extracted (AVE) for each construct should be greater than 0.50 (Fornell \& Larcker, 1981). The discriminant validity between constructs was assessed by determining whether the square root of the AVE for each construct exceeded the correlations between that construct and all other constructs (Fornell \& Larcker, 1981; Chin, 1998). As shown in Table 5, the standardized item loadings ranged from 0.72 to 0.95 , the composite reliability ranged from 0.89 to 0.96 , and the AVE ranged from 0.67 to 0.90 . Table 6 shows that the square root of the AVE for each construct was greater than the correlations between the construct and all other constructs. Thus, all constructs met the criterion for discriminant validity.

Table 5. Assessment of convergent validity

\begin{tabular}{|l|c|c|c|c|c|c|}
\hline \multicolumn{1}{|c|}{ Construct } & Items & Item loadings & $\begin{array}{c}\text { Composite } \\
\text { reliability }\end{array}$ & AVE & $\begin{array}{c}\text { Cronbach's } \\
\text { alpha }\end{array}$ & Weight \\
\hline Human capital (HC) & 3 & $.91-.92$ & .94 & .84 & .90 & 0.49 \\
\hline Organization capital (OC) & 4 & $.72-.87$ & .89 & .67 & .83 & 0.44 \\
\hline Information capital (IC) & 2 & $.93-.93$ & .93 & .87 & .86 & 0.27 \\
\hline Outside-In capability (OIC) & 3 & $.87-.89$ & .91 & .77 & .85 & 0.55 \\
\hline Inside-Out capability (IOC) & 3 & $.85-.90$ & .90 & .76 & .84 & 0.33 \\
\hline Spanning capability (SPC) & 3 & $.90-.93$ & .94 & .85 & .91 & 0.24 \\
\hline General service (GS) & 3 & $.92-.95$ & .96 & .89 & .94 & 0.29 \\
\hline Medical-patient (MP) & 3 & $.90-.94$ & .94 & .84 & .91 & 0.52 \\
\hline Hospital image (HI) & 2 & $.95-.95$ & .95 & .90 & .89 & 0.59 \\
\hline
\end{tabular}


Table 6. Assessment of discriminant validity with cross-loading

\begin{tabular}{|c|r|r|r|r|r|r|r|r|r|}
\hline Construct & \multicolumn{1}{|c|}{ HC } & \multicolumn{1}{c|}{ OC } & \multicolumn{1}{c|}{ IC } & \multicolumn{1}{c|}{ OIC } & IOC & SPC & \multicolumn{1}{c|}{ GS } & \multicolumn{1}{c|}{ MP } & \multicolumn{1}{c|}{ HI } \\
\hline HC & $\mathbf{. 9 2}$ & & & & & & & & \\
\hline OC & .79 & $\mathbf{. 8 2}$ & & & & & & & \\
\hline IC & .62 & .73 & $\mathbf{. 9 3}$ & & & & & & \\
\hline OIC & .72 & .74 & .63 & $\mathbf{. 8 8}$ & & & & & \\
\hline IOC & .68 & .66 & .59 & .79 & $\mathbf{. 8 7}$ & & & & \\
\hline SPC & .55 & .57 & .54 & .56 & .68 & $\mathbf{. 9 2}$ & & & \\
\hline GS & .62 & .61 & .48 & .69 & .69 & .58 & $\mathbf{. 9 4}$ & & \\
\hline MP & .60 & .62 & .44 & .67 & .64 & .53 & .84 & $\mathbf{. 9 2}$ & \\
\hline HI & .57 & .53 & .40 & .55 & .69 & .54 & .70 & .75 & $\mathbf{. 9 5}$ \\
\hline Mean & 4.2746 & 4.0892 & 4.2441 & 4.2253 & 4.2126 & 4.0762 & 4.1311 & 4.4401 & 4.3961 \\
\hline STD & 1.1472 & 1.1118 & 1.2538 & 1.2089 & 1.1271 & 1.1308 & 1.2113 & 1.2290 & 1.1686 \\
\hline * Diagonal values: Square root of the AVE for each construct. \\
* Non-diagonal value: Correlation
\end{tabular}

\section{Results}

Figure 2 shows the results. IC exerted a positive associated on PC (standardized path coefficient: 0.80, significant at .01) and explained $64 \%$ of the variance in PC $(\mathrm{R} 2=0.64)$. Thus, $H 1$ was supported. PC exerted a positive associated with MSP (standardized path coefficient: 0.65 , significant at $.01)$, explained $60 \%$ of the variance in PC with IC (R2 = $0.60)$ together, and $H 2$ was supported. However, IC exerted a nonsignificant effect on MSP (standardized path coefficient: 0.15 , nonsignificant at .01 ), and thus, $H 3$ was not supported.

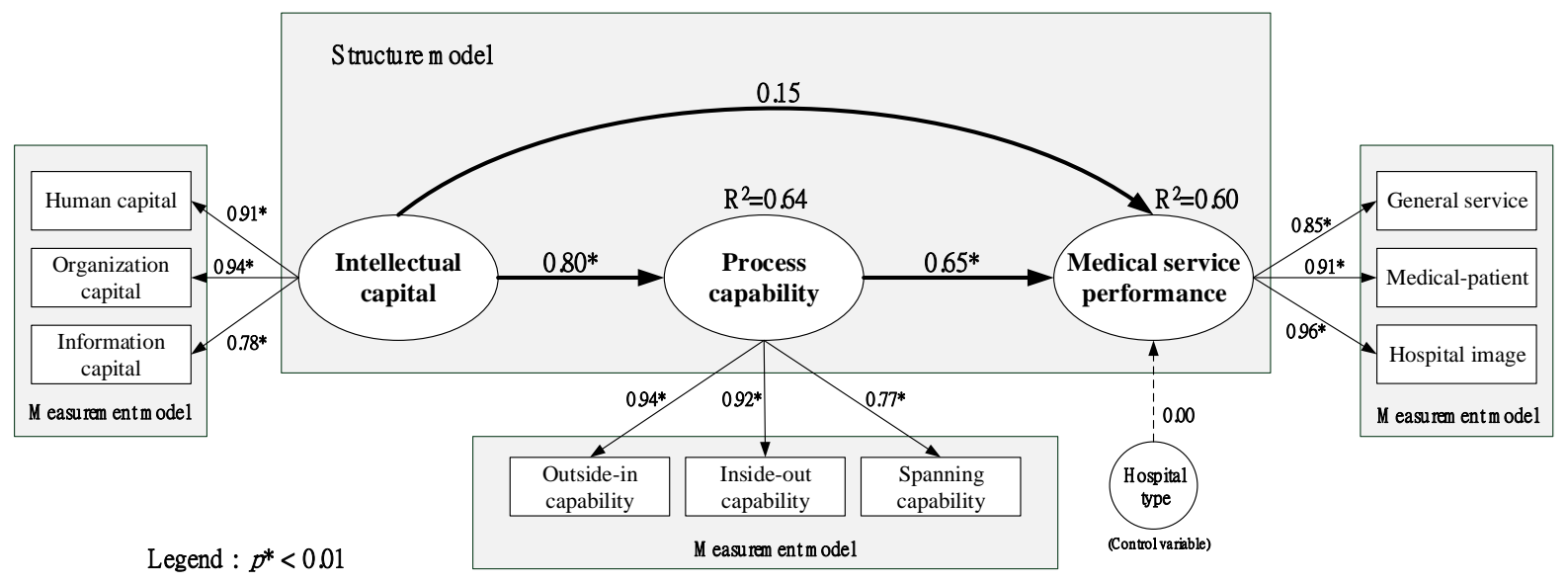

Fig 2. Result of analysis

\section{Limitations}

Although this study provided valuable results, it did have a limitation. The questionnaire was originally tailored for executives and IT managers at hospitals. However, only approximately $11.7 \%$ of the respondents were the senior staff. This may be because at large hospitals, senior managers are often busy and their surrogates complete the questionnaires. This response rate might lead to differences in perspectives regarding intellectual and knowledge-management practices, and it can increase the diversity of data sources and thereby raise the explanatory variance of the variables of interest.

\section{Discussion}

This observation indicated that IC can act as a principal antecedent of PC but not of MSP. The empirical data adequately supported the overall theoretical model. Consequently, IC played a vital role in determining the PC to MSP. Moreover, however, PC played a mediating role between IC and MSP.

As shown in Figure 2, human capital, organizational capital, and information capital are three major components that reflect IC in the health-care industry, and their respective weight scores $(W)$ were $0.91,0.94$, and 0.78 . However, human capital and organizational capital were more important than information capital. PC consists of outsidein, inside-out, and spanning capabilities, and these capabilities exhibited different levels of significance $(W=0.94,0.92$, and 0.77). Outside-in and inside-out capabilities are the two major components of PC. MSP consists of three indicators: general service, medical-patient relationships, and hospital image, and these indicators exhibited different levels of significance ( $W=0.85,0.91$, and 0.96). Patient relationships and hospital images were more important than general service. In 
addition, we found that the specified control variable hospital type was not associated with MSP.

\section{Conclusion}

In general, IC is a major factor in determining the final MSP. MSP cannot be satisfied regardless of the size of IC investments. Specifically, hospitals that have abundant and valuable IC should focus on improving their process capability, which is necessary for achieving high medical service performance. Most studies on organizational performance have focused on the business sector, with few investigating the health-care sector. The most important contributions of this study are that we indicated the understanding of IC impact MSP through PC. Moreover, this study examined three indicators of MSP, general service, medical patient relationships, and hospital image, to prevent the findings from being inconsistent, which has often been the case in previous research on IT-enabled performance. In brief, we provided a new theoretical concept for clarifying MSP and also explained the relationship between IC, PC, and MSP. In addition, a second-order structure was used to analyze the relative importance of indicators informing the main constructs. This structure also provided vital information for effectively constructing the main constructs and conducting analyses in a more standard and systematic manner.

Hospitals should carefully sustain PC in the long term. In this process, the concept is relatively important for the health-care professional to acquire considerable IC. Hospitals are recognized as knowledge-intensive organizations with the responsibility to continually enhance the quality of care. Accordingly, IC-enhanced-MSP requires large investments in IC. Moreover, the senior management of hospitals should consider the time-lag effect on MSP. As to the indicators of MSP, all of them were significant and equally important. The results of this study are expected to provide insight into designing performance evaluation systems for hospital employees and for managing resources efficiently. Accordingly, we suggest that medical professionals must pay attention to the interaction between IC and PC in an evolutional process in order to further improve their expertise.

\section{REFERENCES}

Alkhenizan, A., \& Shaw, C. (2011). Impact of Accreditation on the Quality of Healthcare Services: a Systematic Review of the Literature. Annals of Saudi Medicine, 31(4), 407-416.

Bernroider, E. W.N., Wong, C. W.Y., \& Lai, K. H. (2014). From dynamic capabilities to ERP enabled business improvements: The mediating effect of the implementation project. International Journal of Project Management, 32, 350362

Brahma, S., \& Chakraborty, H. (2011). From Industry to Firm Resources: Resource-Based View of Competitive Advantage. The IUP Journal of Business Strategy, 8(2), 7-16.

Bromiley, P., \& Devaki Rau, D. (2016). Operations management and the resource-based view: Another view. Journal of Operations Management, 41, 95-106.

Cheng, T. M. (2015). Reflections on the 20th Anniversary of Taiwan's Single-Payer National Health Insurance System. Health Affairs, March, 34(3), 502-10.

Chin, W. W. (1998). Issues and Opinion on Structural Equation Modeling. MIS Quarterly, 22(1), 1-11.

Chin, W. W., Marcolin, B. L., \& Newsted, P. R. (2003). A partial least squares latent variable modeling approach for measuring interaction effects: Results from a Monte Carlo simulation study and an electronic-mail emotion/adoption study. Information systems research, 14(2), 189-217.

Coleman, S., Cotei, C., \& Farhat, J. (2013). A Resource-Based View of new firm survival: New perspectives on the role of industry and exit route. Journal of Developmental Entrepreneurship, 18(1), 1-25.

Covell, C. L., \& Sidani, S. (2013a). Nursing intellectual capital theory: operationalization and empirical validation of concepts. Journal of Advanced Nursing, 69(8), 1785-1796.

Covell, C. L., \& Sidani, S. (2013b). Nursing intellectual capital theory: implications for research and practice" OJIN: The Online Journal of Issues in Nursing, 18(2), Manuscript 2.

Devaraj, S., Ow, T. T., \& Kohli, R. (2013). Examining the impact of information technology and patient flow on healthcare performance: A Theory of Swift and Even Flow (TSEF) perspective. Journal of Operations Management, 31(4), 181-192.

Dumay, J. \& Garanina, T. (2013). Intellectual capital research: a critical examination of the third stage. Journal of Intellectual Capital, 14(1), 10-25.

Dzenopoljac, V., Yaacoub, C., Elkanj, N., \& Bontis, N. (2017). Impact of intellectual capital on corporate performance: evidence from the Arab region. Journal of Intellectual Capital, 18(4), 884-903. 
Fornell, C., \& Larcker, D. F. (1981). Structural equation models with unobservable variables and measurement error: Algebra and statistics. Journal of marketing research, 18(3), 382-388.

Francis, P., Agoritsas, T., Chopard, P., \& Perneger, T. (2016). Does the patient's inherent rating tendency influence reported satisfaction scores and affect division ranking? International Journal for Quality in Health Care, 28(2). 221-226.

Gebicki, M., Mooney, Ed., Chen, S. J., \& Mazur, L., A. (2014). Evaluation of hospital medication inventory policies. Health Care Management Science, 17(3), 215-229.

He, A. J. (2014). The doctor-patient relationship, defensive medicine and over prescription in Chinese public hospitals: Evidence from a cross-sectional survey in Shenzhen city. Social Science \& Medicine, 123, 64-71.

Hung, K. Y., \& Jerng, J. S. (2014). Time to have a paradigm shift in health care quality measurement. Journal of the Formosan Medical Association, 113, 673-679.

Hu, Y. P., Chang, I. C., \& Hsu, W. Y. (2017). Mediating effects of business process for international trade industry on the relationship between information capital and company performance. International Journal of Information Management, 37, 473-483.

Inauen, M., \& Schenker-Wicki, A. 2011. The impact of outside-in open innovation on innovation performance. European Journal of Innovation Management, 14(4), 496-520.

Lee, W. I., Chen, C, W., Chen, T, H.., \& Chen, C. H. (2010) The relationship between consumer orientation, service value, medical care service quality and patient satisfaction: The case of a medical center in Southern Taiwan. African Journal of Business Management, 4(4), 448-458.

Ngo, L. V. \& O'cas, A. (2013). Innovation and business success: The mediating role of customer participation. Journal of Business Research, 65(8), 1134-1142.

Serenko, A. \& Bontis, N. (2013). Global ranking of knowledge management and intellectual capital academic journals: 2013 update. Journal of Knowledge Management, 17(2), 307-326.

The World Health Report 2011. (2015). Health System: Improving Performance. Geneva: World Health Organization.

Varagunam M., Hutchings, A., Neuburger, J.. Black N. (2013). Impact on hospital performance of introducing routine patient reported outcome measures in surgery. Journal of Health Services Research \& Policy, 19(2), 77-84.

Westbrook, J. L., Li, L., Georgiou, A., Poaloni, R., \& Cullen J. (2013). Impact of an electronic medication management system on hospital doctors' and nurses' work: a controlled pre-post, time and motion study. Journal of the American Medical Informatics Association, 20, 1150-1158.

World Health Organization. (2013). Quality and Accreditation in Health Care Services: A Global View. Geneva: World Health Organization, Published by the World Health Organization.

Wu, I. J., \& Hu, Y. P. (2012). Examining knowledge management enabled performance for hospital professionals: A dynamic capability view and mediating role of process capability. Journal of the Association for Information Systems, 13(12), 976-999.

Wu, I. J., \& Chen, J. L. (2014). Knowledge management driven firm performance: the roles of business process capabilities and organizational learning. Journal of Knowledge Management, 18(6). 1141-1164.

Wu, T. Y., Majeed, A. Kuo, K. N. (2010). An overview of the healthcare system in Taiwan. London Journal of Primary Care, 3, 115-119.

Zhang, C., Viswanathan, S., \& Henke Jr., J. W. (2011). The boundary spanning capabilities of purchasing agents in buyer-supplier trust development. Journal of Operations Management, 29, 318-328. 